\title{
Severe Refractory Hailey-Hailey Disease Treated With Electron Beam Radiotherapy and Low-Level Laser Therapy
}

Brittany O'Neill Dulmage, MD; Erica R. Ghareeb, MD; John A. Vargo, MD; Timothy J. Patton, DO; Annette E. Quinn, RN; John C. Flickinger, MD

\section{PRACTICE POINTS}

- Hailey-Hailey disease (HHD) is a rare blistering dermatosis characterized by recurrent erythematous plaques with a predilection for the intertriginous areas.

- Electron beam radiotherapy is a potential treatment option for local control in patients with recalcitrant HHD.

To the Editor:

Hailey-Hailey disease (HHD), or familial benign chronic pemphigus, is a genetic disorder caused by an autosomal-dominant mutation in ATPase secretory pathway $\mathrm{Ca}^{2+}$ transporting 1 gene, ATP2C1, which disrupts intracellular calcium signaling and blocks synthesis of junctional proteins required for cell-cell adhesion. ${ }^{1,2}$ As a result, patients develop acantholysis of the suprabasilar epidermis resulting in chronic flaccid blisters and erosions, particularly in intertriginous areas. ${ }^{3}$ Patients often report associated itching, pain, and burning, and they frequently present with secondary polymicrobial infections. ${ }^{4}$ Although HHD is genetic, patients may present without a family history due to variable expressivity and sporadic germline mutations. ${ }^{5}$ Therapeutic options are numerous, and patients may attempt many treatments before a benefit is observed. ${ }^{4}$ Local disease improvement was noted in a case series of 3 patients treated with electron beam radiotherapy with no disease recurrence in treated sites at 38, 33, and 9 months' follow-up. ${ }^{6}$ Herein, we present a case of HHD refractory to numerous prior therapies that was successfully treated with electron beam radiotherapy, highlighting the potential role for palliative radiotherapy in select refractory cases of HHD.

A 35 -year-old woman with a 7 -year of history of HHD presented with severe recalcitrant disease including extensive erosive patches and plaques in the intertriginous areas of the bilateral axillae, groin, and inframammary folds (Figure 1). The skin eruptions first appeared at 28 years of age after her last pregnancy and continued as painful blistering that worsened with each menstrual cycle. Initially the affected desquamated skin would heal between menstrual cycles, but large areas of desquamation remained unhealed in the groin and inframammary regions throughout her full menstrual cycles by the time of referral. Family history included 4 family members with HHD: 2 aunts, an uncle, and a cousin on the paternal side of her family. Over a 7-year period, treatment with clobetasol cream, clindamycin gel, tacrolimus ointment, doxycycline, dapsone, cyclosporine, methotrexate, etanercept, isotretinoin, and prednisone (15 mg every other day) all failed. Most recently, axillary abobotulinumtoxinA injections were attempted but failed. She had been prednisone dependent for more than 1 year. Due to the ongoing refractory disease, she was referred to radiation oncology to discuss radiotherapy treatment options.

Drs. O'Neill Dulmage, Vargo, Patton, and Flickinger as well as Ms. Quinn are from the University of Pittsburgh, Pennsylvania. Dr. O'Neill Dulmage is from the School of Medicine; Drs. Vargo and Flickinger as well as Ms. Quinn are from the Department of Radiation Oncology; and Dr. Patton is from the Department of Dermatology. Dr. Ghareeb is from the Department of Medicine, Section of Dermatology, West Virginia University, Morgantown. The authors report no conflict of interest. Correspondence: Erica R. Ghareeb, MD, Department of Medicine, Section of Dermatology, PO Box 9158, Morgantown, WV 26506 (erghareeb@hsc.wvu.edu). doi: $10.12788 /$ cutis.0178 
At the time of presentation to the radiation oncology clinic, she continued to have extensive involvement of the intertriginous areas as well as involvement of the right neck at sites of skin chafing from clothing. Consistent with the limited available evidence, a dose of 20 Gy in 10 fractions was first prescribed to the axillae to assess response in the event of radiosensitivity, resulting in brisk desquamation. The conventional fractionation of 2 Gy per fraction allowed for assessment of response/ tolerance and the opportunity to stop the treatment in the unlikely event of a severe skin reaction. Her skin tolerated treatment well with slight dryness and mild irritation that was less severe than the typical HHD flares. Concurrently with the axillary radiotherapy, we delivered
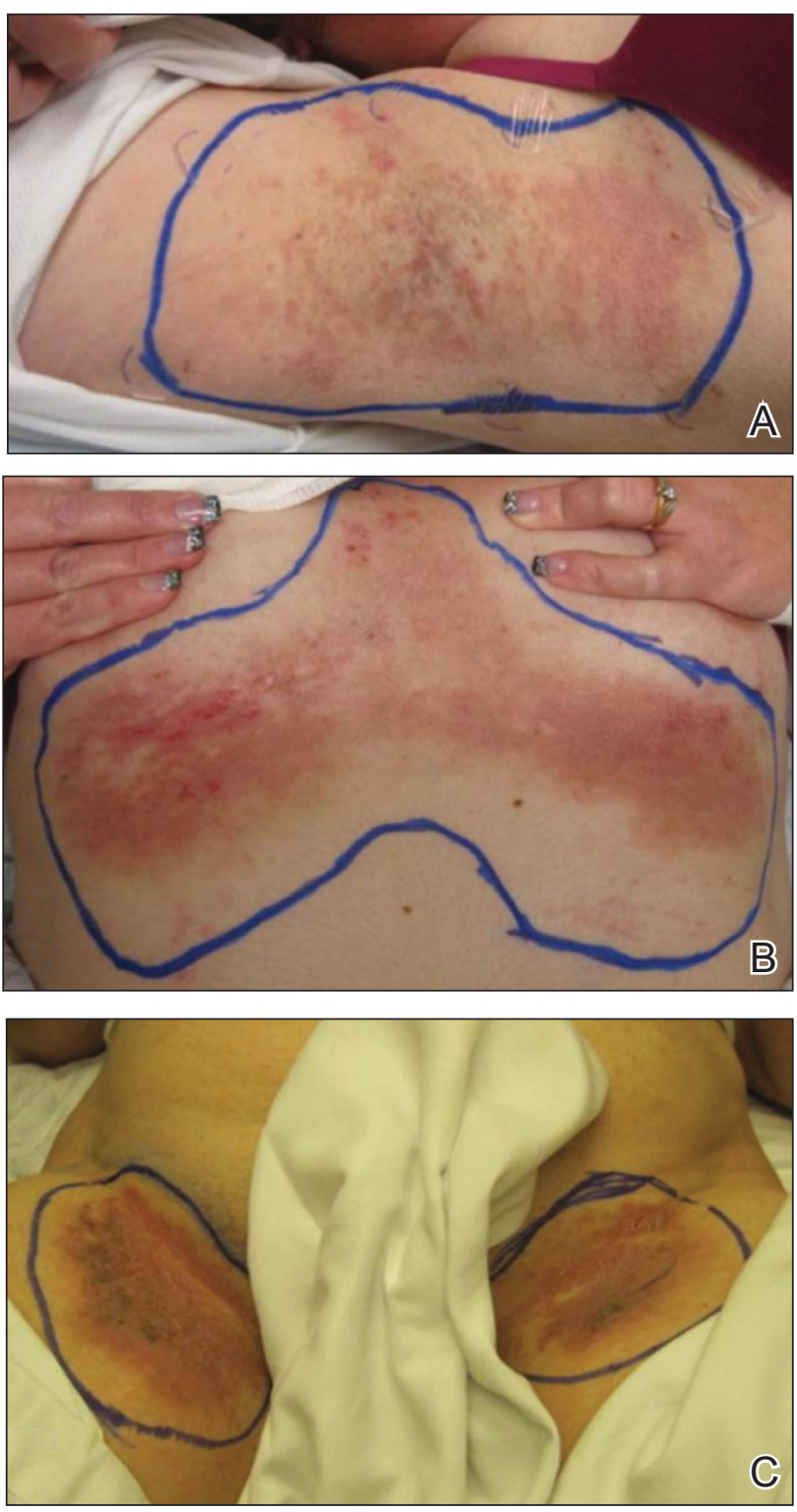

FIGURE 1. Hailey-Hailey disease. A-C, Preradiotherapy involvement of the axilla, inframammary folds, and groin, respectively. a trial of low-level laser therapy to areas of severe disease in both inguinal regions in the hope that it could be used instead of radiotherapy to avoid any associated risks of radiation. Low-level laser therapy was administered with a light-emitting diode cluster probe at $2.5 \mathrm{~Hz}$ for 1 minute to 2 sites in each inguinal area daily for a total of 10 treatments. Unfortunately, this therapy temporarily exacerbated exudation present in the skin before it resolved to its pretreatment state with no improvement.

One month after treatment she had total resolution of the erosive patches and plaques with mild residual hyperpigmentation in the axillae, establishing that radiation therapy was reasonably effective. To lower the total radiation dose and decrease the risk of radiation-induced malignancy, we treated the bilateral groin and the inframammary region with a treatment schedule of 8 Gy in 2 fractions at a higher dose of 4 Gy per fraction instead of 2 Gy. At 12 days posttreatment, she had a dramatic response in the groin and a mixed response in the inframammary region, with a focus that had not yet regressed. Given the dramatic response in the treated sites, the patient requested treatment to the right side of the neck. Thus, we treated this area with a similar 8 Gy in 2 fractions, and an additional 6 Gy in 2 fractions boost was added to the slow responding focus in the inframammary fold for a total of 14 Gy in 4 fractions. The patient tolerated all treatments well with mild grade 1 skin irritation that was unlike the blistering of the typical HHD flares. Two months following completion of the first course of radiotherapy to the axillae and 2 weeks from the most recent course, she tapered off her prednisone regimen (15 mg every other day) but had a relapse of disease with her subsequent menstrual cycles that presented as a blistering skin reaction in the inframammary region, which healed in response to restarting steroids. This flare was less severe than those prior to radiotherapy. At 10 months posttreatment, the patient was free of disease in the neck and axillae (Figure 2). She continued to have relapses in the inframammary region with menstrual cycles and noted new disease in the popliteal regions; however, the relapses were less severe, and her skin had improved more with radiation than any of the prior therapies.

Our experience with low-level laser therapy indicated that it should be completely avoided in HHD. Our patient's treatment with radiotherapy demonstrated excellent short-term responses in areas of pemphigus but later proved to be a mixed response with further followup including a mild posttreatment flare of the inframammary region that responded to steroids and new popliteal region involvement. As summarized in the Table, earlier reports of radiotherapy for the treatment of HHD have yielded varied results. ${ }^{6-8}$ The mixed response seen in our patient suggests that response to radiotherapy may be site specific, related to underlying inflammation from microbial overgrowth, or a function of the disease severity.

Although the number of reports on radiotherapy in HHD is small, there have been several reports of 


\section{Summary of Reported Cases for Hailey-Hailey Disease Treated With Radiotherapy and Associated Outcomes}

\begin{tabular}{|c|c|c|c|c|c|}
\hline \multirow{2}{*}{$\begin{array}{l}\text { Reference } \\
\text { (year) }\end{array}$} & \multirow{2}{*}{$\begin{array}{l}\text { Patient } \\
\text { no. }\end{array}$} & \multirow{2}{*}{$\begin{array}{l}\text { Treatment } \\
\text { area(s) }\end{array}$} & \multirow[b]{2}{*}{ Dose } & \multicolumn{2}{|c|}{ Outcome } \\
\hline & & & & Initial & Long-term \\
\hline \multirow[t]{6}{*}{$\begin{array}{l}\text { Sarkany } \\
\text { (1959) }\end{array}$} & 1 & $\begin{array}{l}\text { Axillae, } \\
\text { groin }\end{array}$ & $\begin{array}{l}3 \times 2.0 \text { Gy } \\
(R \text { axilla } \times 2) \\
3 \times 3.0 \text { Gy } \\
(L \text { axilla and groin) }\end{array}$ & $\begin{array}{l}\text { Initial clearance at all } \\
\text { treated sites }\end{array}$ & $\begin{array}{l}R \text { axilla required } \\
\text { re-treatment at } 5 \mathrm{mo}\end{array}$ \\
\hline & 2 & $\begin{array}{l}\text { Axillae } \times 2 \text {, } \\
\text { groin } \times 2 \text {, } \\
\text { neck, thighs }\end{array}$ & $\begin{array}{l}3 \times 2.0 \text { Gy } \\
\text { (axillae, groin } \times 1), \\
3 \times 3.0(\mathrm{R} \text { groin } \times 1) \text {, } \\
2 \times 2.0 \\
(\mathrm{~L} \text { groin } \times 1, \text { thighs), } \\
1 \times 4.0 \text { (neck) }\end{array}$ & $\begin{array}{l}\text { Initial clearance at all } \\
\text { treated sites }\end{array}$ & $\begin{array}{l}\text { Axillae re-treated at } \\
6 \text { mo, disease controlled } \\
\text { for } 16 \text { mo total }\end{array}$ \\
\hline & 3 & $L$ groin & $3 \times 3.0$ Gy & Initial clearance of $\mathrm{L}$ & $\begin{array}{l}\text { L groin clear at } \\
14 \text { mo, some disease } \\
\text { in untreated } R \text { groin }\end{array}$ \\
\hline & 4 & R elbow flexure & $3 \times 2.0$ Gy & $\begin{array}{l}\text { Hyperpigmentation at } \\
\text { treated site, mild scale }\end{array}$ & $\begin{array}{l}\text { Mild scaling noted at } \\
8 \mathrm{mo}\end{array}$ \\
\hline & 5 & Axillae, groin & $3 \times 3.0$ Gy & $\begin{array}{l}\text { Initial clearance at all } \\
\text { treated sites }\end{array}$ & $\begin{array}{l}\text { Disease recurrence } \\
\text { noted in groin } 7-10 \mathrm{mo} \\
\text { posttreatment }\end{array}$ \\
\hline & 6 & Groin, scrotum & $\begin{array}{l}3 \times 3.0 \text { Gy (groin), } \\
3 \times 2.0 \text { Gy (scrotum) }\end{array}$ & $\begin{array}{l}\text { Clearance in groin, no } \\
\text { improvement in scrotum }\end{array}$ & Groin clear at $8 \mathrm{mo}$ \\
\hline \multirow[t]{2}{*}{$\begin{array}{l}\text { Roos and } \\
\text { Reid }^{8} \\
\text { (2002) }\end{array}$} & 1 & $\begin{array}{l}\text { Groin } \times 5 \text {, } \\
\text { thigh, axillae, } \\
\text { back }\end{array}$ & $\begin{array}{l}4 \times 2.0 \text { Gy (groin } \times 4), \\
5 \times 3.0 \text { Gy (groin } \times 1, \\
\text { thigh), } 10 \times 2.0 \text { Gy }\end{array}$ & $\begin{array}{l}\text { Partial response of } \\
\text { groin only }\end{array}$ & $\begin{array}{l}\text { Failure by } 5 \text { mo, } \\
\text { unchanged at } 68 \mathrm{mo}\end{array}$ \\
\hline & 2 & & $\begin{array}{l}5 \times 3.0 \text { Gy } \\
(\text { groin } \times 1) \\
\text { and } 10 \times 2.0 \text { Gy } \\
(\text { groin } \times 1 \text { ) }\end{array}$ & Partial response at all sites & $\begin{array}{l}\text { Failure by } 5 \text { mo, } \\
\text { decreased severity } \\
\text { at } 58 \mathrm{mo}\end{array}$ \\
\hline \multirow[t]{3}{*}{$\begin{array}{l}\text { Narbutt et al } \\
\text { (2010) }\end{array}$} & 1 & axillae & $10 \times 2.0$ Gy & $\begin{array}{l}\text { Grade } 1 \text { skin reaction and } \\
\text { no new disease at } 2 \text { mo }\end{array}$ & $\begin{array}{l}\text { No disease recurrence } \\
\text { at } 38 \mathrm{mo}\end{array}$ \\
\hline & 2 & Bilateral axillae & $10 \times 2.0$ Gy & Grade 1 skin reaction & No new lesions at $33 \mathrm{mo}$ \\
\hline & 3 & Bilateral axillae & $11 \times 2.0$ Gy & None & $\begin{array}{l}\text { Axillae clear at } 9 \text { mo, } \\
\text { ongoing inframammary } \\
\text { disease }\end{array}$ \\
\hline Current case & & $\begin{array}{l}\text { Axillae, groin, } \\
\mathrm{R} \text { neck, } \\
\text { inframammary } \\
\text { region }\end{array}$ & $\begin{array}{l}10 \times 2.0 \text { Gy (axillae), } \\
2 \times 4.0 \text { Gy (groin), } \\
2 \times 4 \text { Gy (R neck), } \\
2 \times 4.0 \text { Gy and } \\
2 \times 3.0 \text { Gy } \\
\text { (inframammary) }\end{array}$ & $\begin{array}{l}\text { Grade } 1 \text { skin reaction, no } \\
\text { disease in groin or axillae, } \\
\text { mild disease in the neck and } \\
\text { inframammary areas }\end{array}$ & $\begin{array}{l}\text { Axillae } 10 \text { mo clear, } \\
\text { neck } 9 \text { mo clear, } \\
\text { recurrence } \\
\text { inframammary and groin, } \\
\text { new popliteal disease }\end{array}$ \\
\hline
\end{tabular}

Abbreviations: R, right; L, left. 

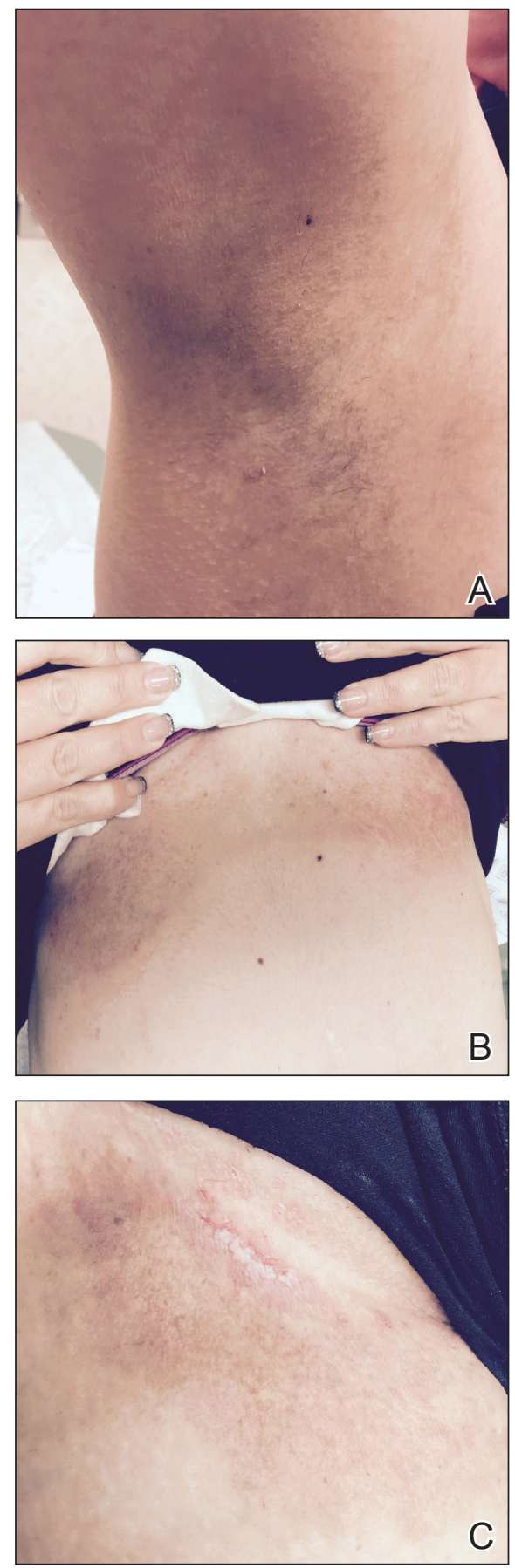

FIGURE 2. Hailey-Hailey disease. A-C, Postradiotherapy follow-up of the axilla, inframammary folds, and groin, respectively.

Darier disease, another acantholytic autosomal-dominant genodermatosis affecting the ATP2A2 gene, successfully treated incidentally with radiation. ${ }^{9,10}$ Total skin electron beam therapy also has been employed in the treatment of Darier disease; this patient experienced a severe flare after a relatively low treatment dose that required intensive care monitoring, possibly highlighting the potential radiosensitivity of patients with underlying genodermatoses and cautioning against radiotherapy dose escalation. ${ }^{11}$ In light of the mixed responses seen, radiation therapy should be used sparingly for severe relapsing cases that have failed a plethora of prior treatments. The risk of second cancer induction is especially of concern when using radiotherapy in a benign disease. ${ }^{12}$ We observed excellent initial responses in our patient, both with conventionally fractionated radiotherapy and hypofractionation. The risk of second malignancy induction is a linear function of radiotherapy dose. ${ }^{12}$ Thus, utilization of hypofractionated regimens such as 4 Gy times 2 fractions seems most prudent. It remains unclear if further dose de-escalation may yield a similar response, as seen in studies utilizing radiotherapy for other benign disease. ${ }^{13,14}$ Overall, given our mixed results with short follow-up, we conclude that the consideration of radiotherapy should be limited to patients with severe recalcitrant HHD.

\section{REFERENCES}

1. Dhitavat J, Fairclough RJ, Hovnanian A, et al. Calcium pumps and keratinocytes: lessons from Darier's disease and Hailey-Hailey disease. Br J Dermatol. 2004;150:821-828.

2. Hu Z, Bonifas JM, Beech J, et al. Mutations in ATP2C1, encoding a calcium pump, cause Hailey-Hailey disease. Nat Genet. 2000;24:61-65.

3. Burge SM. Hailey-Hailey disease: the clinical features, response to treatment and prognosis. Br J Dermatol. 1992;126:275-282.

4. Chiaravalloti A, Payette M. Hailey-Hailey disease and review of management. J Drugs Dermatol. 2014;13:1254-1257.

5. Zhang F, Yan X, Jiang D, et al. Eight novel mutations of ATP2C1 identified in 17 Chinese families with Hailey-Hailey disease. Dermatology. 2007;215:277-283.

6. Narbutt J, Chrusciel A, Rychter A, et al. Persistent improvement of previously recalcitrant Hailey-Hailey disease with electron beam radiotherapy. Acta Derm Venereol. 2010;90:179-182.

7. Sarkany I. Grenz-ray treatment of familial benign chronic pemphigus. Br J Dermatol. 1959;71:247-252.

8. Roos DE, Reid CM. Benign familial pemphigus: little benefit from superficial radiotherapy. Australas J Dermatol. 2002;43:305-308.

9. Podgornii A, Ciammella P, Ramundo D, et al. Efficacy of the radiotherapy on Darier's disease: an indirect evidence. Case Rep Dermatol Med. 2013;2013:907802.

10. Mac Manus MP, Cavalleri G, Ball DL, et al. Exacerbation, then clearance, of mutation-proven Darier's disease of the skin after radiotherapy for bronchial carcinoma: a case of radiation-induced epidermal differentiation? Radiat Res. 2001;156:724-730.

11. Kittridge A, Wahlgren C, Fuhrer R, et al. Treatment of recalcitrant Darier's disease with electron beam therapy. Dermatol Ther. 2010;23:302-304.

12. Preston DL, Shimizu Y, Pierce DA, et al. Studies of mortality of atomic bomb survivors. report 13: solid cancer and noncancer disease mortality: 1950-1997. Radiat Res. 2003;160:381-407.

13. Fröhlich D, Baaske D, Glatzel M. Radiotherapy of hidradenitis suppurativa-still valid today? [in German]. Strahlenther Onkol. 2000;176:286-289.

14. Heyd R, Tselis N, Ackermann H, et al. Radiation therapy for painful heel spurs: results of a prospective randomized study. Strahlenther Onkol. 2007;183:3-9. 